\title{
Vocational Education and Training for Development: a policy in need of a theory?
}

\author{
Simon McGrath, University of Nottingham
}

\begin{abstract}
The current decade has seen a significant return of interest in vocational education and training (VET) amongst the international policy community. This rise in policy and programmatic interest in VET's role in development, however, stands in contrast to the state of the academic debate. Whilst there have continued to be both policy and academic developments in VET in OECD countries; in the South there has been a paucity of VET research and little in the way of theoretical exploration. Rather, the academic orthodoxy in the international education and development field is dismissive of VET's possible contribution. Given the return of the policy interest in VET for development, and the possibilities of a broader vision of education-development relations beyond 2015, when the MDGs end, it is time to revisit the role of VET in development from an explicitly theoretical stance.
\end{abstract}

In this article, I argue that the current approach to VET is grounded in an outmoded model of development, whilst the academic critique of VET in developing countries is clearly long outdated. In contrast, I examine the implications for VET of recent trends in thinking about development through the exploration of three particular theoretical approaches: human rights, capabilities and integrated human development. I conclude by considering the purposes, natures and possibilities of VET as a means of human development.

\section{Introduction: the Rebirth of Vocational Education and Training}

The current decade has seen a significant return of interest in vocational education and training (VET) amongst the international policy community. Indeed, 2012 will see two major reports from UNESCO (one of the Global Monitoring Report series and a World Report on Technical and Vocational Education and Training ${ }^{1}$ ); with the latter serving as the key input to the Third International Congress on TVET, to take place in Shanghai in May. In the past three years, UNESCO has announced a new sectoral strategy; a new Inter Agency Group on VET has been launched; and international (e.g., G20) and regional (e.g., SADC) structures have signalled new or renewed interest in VET matters. This multilateral policy trend appears to reflect a slightly earlier return to VET at national levels, with official development assistance from the Development Assistance Committee donors to "vocational training" having increased threefold between 2002 and 2009 (King and Palmer, 2011: 24).

This rise in policy and programmatic interest in VET.s role in development, however, stands in contrast to the state of the academic debate. Whilst there have continued to be both policy and academic developments in VET in OECD countries; in the South there has been a paucity of VET research and little in the way of theoretical exploration. Rather, the academic orthodoxy in the international education and development field is dismissive of VET's possible contribution. Indeed, it appears that the debate stopped more than twenty years ago, as far as many education researchers are concerned. First, the thesis that basic education was the most important element of education for development was cemented in place by the World Conference on Education for All (EFA)

\footnotetext{
1 The forthcoming UNESCO World Report, for which I am one of the editorial team, is also explicitly attempting to reimagine VET but from a broader range of perspectives than I am concerned with in this paper. My thinking here, inevitably, has been influenced by my colleagues in the UNESCO project but this paper is not a formal input into that collective work and is not a reflection of UNESCO's thinking.
} 
at Jomtien in 1990. Second, this was reinforced the following year by the World Bank's policy paper on VET (World Bank, 1991). Drawing on a sceptical tradition regarding VET, building on the early insights of Foster (1965) and including a range of donor agency work, mostly from the World Bank (e.g., Psacharopoulos, 1981 and 1985; Psacharopoulos and Loxley, 1985; Heyneman, 1985; Lauglo and Lillis, 1988), this appeared to show conclusively that public VET was inefficient and ineffective. 20 years have followed in which it has been clear that there is little incentive for researchers to work on VET in developing countries, whilst the millennium development goals (MDGs) have encouraged a continuation of the view that VET is unimportant.

Nonetheless, there has continued to be a small literature on VET and development, and IJED has been an important source for this (e.g., Bennell, 1996; Bennell and Segerstrom, 1998; King and Martin, 2002; King, McGrath, Rose, 2007; Palmer, 2007 and 2009; McGrath and Akoojee, 2007 and 2009; King, 2009; Lewis, 2009). However, this has not sought to engage much with either the ongoing fashion for VET in OECD countries (and the rich literature produced there) or with new trends in development theory.

Given the return of the policy interest in VET for development, and the possibilities of a broader vision of education-development relations beyond 2015, when the MDGs end, it is time to revisit the role of VET in development from an explicitly theoretical stance: hence this special issue, which seeks to begin a reconceptualisation of VET-development linkages.

In this article, I will take a line that explicitly stands outside the dominant view. I will argue that the current approach to VET is grounded in an outmoded model of development, whilst the academic critique of VET in developing countries is clearly long outdated (cf. McGrath, 2011). In contrast, I will examine the implications for VET of recent trends in thinking about development (cf. Muller, 2011). This will lead me to consider the purposes, natures and possibilities of VET as a means of human development.

Necessarily, an article can go only so far in such an ambitious direction. It must simplify much that is complex and I will provide brief accounts of major literatures that will underplay both their complexity and their interactions. My intention is not to offer a formal new theory but rather to offer a series of lenses and directions through which a wider debate on the role of VET in development could be built.

These lenses are not intended to be the sum of possible lenses. For instance, I only touch on the sustainable development paradigm (but see an earlier IJED special issue 29/ 2 ), and do not engage with certain recent elements of economic development debates, such as exogenous growth and the revived developmental states account, valuable though these are (cf. Edigheji, 2010). Equally, I will refer only briefly to the large VET-in-developed-countries literature. The bringing together of these literatures is an important task, and is one for which Allais's article in this special issue is particularly valuable.

Before progressing to my main arguments, it is necessary to step carefully into the morass of definitions (cf. Karmel, 2011). Whilst we have a strong international sense of what a school looks like, the area of VET is less certain and terminology has proliferated. In English alone, one can find a range of terms, including vocational education, vocational education and training, technical and vocational education and training, skills development, workforce development and human resources development, and many more. Whilst these terms may be seen as distinct by some users; they are also often used interchangeably. Moreover, the meaning given to a particular term can vary, even amongst neighbouring countries. Whatever the term used, there are debates as to whether what is being talked about and planned for includes public and private (forprofit 
and not-for-profit) providers; basic, intermediate and advanced skills formation; formal and informal sector workplaces; learning in enterprises and in educational institutions; formal, non-formal and informal modes of learning; pre-employment programmes and continuing occupational and professional development. Views about what is to be included and which institutional forms deliver specific forms vary over both time and space. Moreover, we are seeing an increasing hybridity of form and a blurring of the general-vocational barrier. Thus, any definition of vocational education and training is highly problematic. In the broadest sense, VET is conventionally understood as encompassing the myriad forms of learning that are primarily aimed at supporting participation in the worlds-of-work, whether in terms of (re)integration into work or increased effectiveness of those currently defined as being in work. Nonetheless, even this tentative definition is problematic. The notion of "being in work" is frequently used in ways that ignore much of female labour, whilst the focus on "worlds-of-work" can lead to the exclusion of a consideration of the broader notion of the vocation of being human. Indeed, the limitations of any such definition lie at the heart of the concerns of this article. To make my task possible, I will proceed with an assumption that VET is a set of practices and technologies more than a clearly defined concept.

The article has two main sections, although of uneven length. In the first, I briefly examine the orthodoxy of VET for economic development. Then, I move on to the larger section in which I examine trends in development theory and consider their implications for VET. I then summarise my arguments and consider their implications in a concluding section.

\section{The Orthodoxy: VET for Economic Development}

The dominant account of VET fits squarely in what Giddens (1994) has described as productivism. In this account, late modernity has seen paid employment's separation off from other aspects of life and the enshrining of economic development as the ultimate goal of society. Anderson (2009) builds on these arguments to claim that VET is built on two key productivist assumptions:

1. training leads to productivity, leads to economic growth (training for growth)

2. skills lead to employability, lead to jobs (skills for work).

It is worth quoting him at length:

cast within the ethos of productivism and the ideological framework of neoliberalism, the institution of TVET is based on a restricted and instrumental view of lifeworlds which reduces people and the environment to the status of human and natural resources for economic exploitation. Such a perspective overlooks the complex and interdependent nature of human existence, the source and meanings of which are inextricably linked to the social relations, cultural practices and natural material conditions. TVET students are not only already, or aiming to become, workers. They are also human beings and citizens with a wide range of needs, relationships, duties, aspirations and interests beyond work; in the family, the local community, in civil society and the global environment. Over their life course, they give birth, raise and care for family members, consume goods and services, manage finances, fall ill, experience unemployment and hardship, elect governments, get involved in community affairs and ultimately rely for their survival on the fruits of nature. Yet in TVET they learn only to labour and produce commodities. (Anderson, 2009: 44-5)

Thus, Anderson sees the dominant model as impoverished in its view of skills, work and life; trapped in the implications of the neoliberal shift of the 1980s. Whilst I agree with 
his critique of the limitations of the approach, I do not concur with his view of its historical evolution. Rather, I think neoliberalism is acting here as a default bogeyman. Instead I follow IJED's former editor, Watson (1994), in seeing the dominant model of VET as older, being closely related to the big push model of development of the $1960 \mathrm{~s}$ through which a Western view of development permeated the rest of the world. In this, VET helped to reinforce the spread of a monolithic account of industrialisation, modernisation and paid work. Indeed, this reading is implicitly supported by Fischer (2009), who notes that the Washington Consensus tends to neglect the role of industry and production in development, in comparison to the approaches of the 1950s and 1960s. Whilst VET is an increasingly popular policy tool, it remains of little interest to development economists.

This discussion helps us towards a better understanding of why it is that the state retains a very significant role in the provision of VET globally, notwithstanding the neoliberal turn. Indeed, this allows us intellectual purchase on a central tension of the most influential text on VET in developing countries: the World Bank's 1991 policy paper.

Whilst this paper shows a very clear ideological preference for market solutions, reflecting the wider stance of the Bank; the pragmatic nature of the Bank as an institution that needs to lend money to survive requires it to deal with feasible policy options. This meant that much of its focus in the VET policy paper was on the reform of public providers, in spite of a strong sense that these were largely failing, and that market-based approaches were the answer.

Whilst there have been developments of tools such as levy-grant systems and training vouchers, which can help stimulate private VET markets, the international norm is that much of formal VET ${ }^{2}$ is provided by governments and so the major policy thrust of the past 20 years has been to transform public provision. In keeping with other areas of public policy, this has resulted in approaches that have drawn heavily on the new public management (NPM) paradigm (cf. McGrath, 2010a for the South African case).

This has resulted in a VET toolkit that has spread globally. ${ }^{3}$ At its heart is a move to reform public provider institutions so that they are simultaneously more autonomous from old style state bureaucracy and more accountable to the leaner NPM state, business and learners. Together with learners, these institutions are now charged with maximising employability, a notion that is increasingly colonising public universities too.

Although there is a large toolkit, the five principal tools used internationally are:

. systemic (and sometimes sectoral) governance reforms - focused on taking some of the authority for direction of the VET system out of the bureaucracy but also giving more power to shape policy directions to employers. This is presumed to make vocational learning more relevant and responsive.

. qualifications frameworks - aiming to make qualifications more transparent to all stakeholders; to encourage vertical and horizontal movement of learners within learning systems; and to facilitate the wider accreditation of informal and nonformal learning.

\footnotetext{
${ }^{2}$ This is not to say that the bulk of VET is formal and public. Much of formal provision takes place through private providers or employers; whilst informal learning and learning in informal enterprises are also major elements of the international VET landscape - see King (this issue) for the Indian case. Rather, the narrow point here is simply one about conventional approaches to public VET policy. The forthcoming UNESCO World TVET Report will provide an extensive analysis of VET understood more broadly.

${ }^{3}$ See Lugg and McGrath (this issue) for the implications of this for VET policy learning.
} 
. quality assurance systems - designed to ensure that VET providers have internalised notions of quality and continuous improvement; and, often, intended to allow stakeholders to have confidence in the quality of providers through accreditation and inspection structures.

. new funding mechanisms - signalling a shift away from block funding of public providers to a regime in which funding is more outcomes-oriented and institutionally-neutral.

. managed autonomy for public providers - introducing new governance structures designed to give a larger voice to stakeholders (especially industry); and greater autonomy for providers to be the locus of decision making; but, also, a requirement to respond to national policy directions and to perform against targets promoted through funding, reporting and inspection regimes.

I do not wish to reject the orthodoxy completely. VET must have a major focus on the worlds-of-work. Moreover, this model can be claimed to have had some successes (cf. Cedefop, 2011), and the poor reputation of conventional VET is seriously overstated by those who rely still on data from more than a quarter century ago (cf. McGrath, 2011). Nonetheless, there is a series of limitations with this account both in terms of its theoretical power and its practical efficacy. It is too individualistic in its assumptions regarding its chief goal of employability. It is too short-term in its focus on immediate employability rather than lifelong processes. It is too focused on a particular model of work as paid employment, with very serious gender implications. In spite of the influences of neoliberalism, it is still too focused on delivery by public institutions; ignoring the complexity of forms of delivery and acquisition of vocational learning. It remains too centred on formal learning in educational institutions, largely heedless of the wealth of literature on informal learning. It is too uninterested in wider questions of preparation for the good life, ignoring the capabilities turn in particular. It is unsustainable in the face of major global challenges regarding environmental degradation and climate change, which it domesticates as "skills for green jobs".

Moreover, there is insufficient evidence that the reforms have had significant positive impacts on either economic competitiveness or social inclusion.

Elements of this critique have been widely made within the academic VET community in OECD countries (e.g., Colley et al., 2003; Unwin, 2004; Brockmann, Clarke and Winch, 2011; Strathdee, 2011), but they have not been adequately explored in terms of the consequences for the South. As Anderson and Watson both highlight, these are not simply a set of internal weaknesses within our understanding of how VET works, but they are problems that are located within a wider development paradigm. It is not so much that our model of VET is impoverished but that its impoverishment lies in its implicit grounding within an outmoded and inadequate development paradigm. Returning to Giddens, VET is located within a view of development that is narrowly economic and productivist. Yet, this is not a true reflection of what it means to be human. Indeed, since at least the time of the first Human Development Report in 1990 (UNDP, 1990), there has been a shift in development theory that has seen a far wider acceptance of arguments that seek to place humans rather than money at the heart of development. As VET is about humans learning, working and living, it is imperative that it draws more consciously from this rich stream of theoretical insights. An attempt to begin such a project is the subject of the second, and larger, section of this article. 
Pre-Press copy of paper in IJED 32/5

doi: http://dx.doi.org/10.1016/j.ijedudev.2011.12.001

\section{Re-thinking Development: Human-Centred Development and its Implications for VET}

There is a huge range of concepts that have emerged which seek to stress the need to go beyond economistic understandings of development. Some hark back to far older philosophical notions of the good life and human flourishing, whilst others invest terms such as capabilities, well-being and security with radically shifted meanings. In what follows, I will focus on just three aspects of this broader set of approaches: human rights, human development and capabilities, and integrated human development. These are intended as illustrations of the broad possibilities for vocational learning that emerge from a broader development vision, but are chosen for their power in adding significant value to our understanding of the VET-development relationship.

\section{Human Rights}

The human rights approach to development is closely related to the history of the United Nations. The Universal Declaration on Human Rights (UN, 1948) was the first major statement of the UN subsequent to its founding charter and provided the basis for the development of an international theory and practice of human rights. The human rights approach focuses on what individuals have a right to as humans. It encourages particular attention to the weakest and poorest in society and has clear resonances in later conceptual progress in human-centred development accounts, including basic needs, capabilities and the MDGs.

Its origins in the aftermath of the second world war and the foundation of the UN serve to imbue the human rights approach with a powerful moral force. However, it has tended towards legalism and towards universalistic notions of justice, as exemplified by Rawls's (1971) theory of justice. Nonetheless, this tendency towards universalism and legalism has been somewhat countered in recent years by a broader and more flexible sense of how human rights need to be understood in a complex world (e.g., Alston and Robinson, 2005).

As was already noted, the human rights account can be seen as playing a key role in the development of the MDGs (cf. Unterhalter, 2005). However, arguably the most important work on developing a human rights perspective on education comes from the late UN Special Rapporteur on the Right to Education, Katerina Tomasevski. She suggests that we need to think about accessibility in four ways:

. availability of provision at the systemic level;

. access in practice;

. acceptability in terms of quality, process and content; and

. adaptability to the needs of individuals and groups. (Tomasevski, 2001)

Although the focus of Tomasevski was very strongly on schooling, each of these considerations can be applied specifically to VET. First, we can examine whether there are policy frameworks in place that guarantee VET access for all, or at least for more, people. We can explore the extent to which policy commitments specify particular groups, such as youth, women or people living with disabilities. We can consider to what extent such policies are limited to thinking about formal education or incorporate wider human resources perspectives that include the training functions of other ministries as well as non-formal and private provision; and also learning that takes place in formal and informal workplaces, in communities and in homes. 
Tomasevski's second focus is on practical access. This can lead us to question whether there are sufficient sites and modes of VET learning practically available - i.e. within physical or financial reach - for those who want to access them. In this light, it is vital to remember that most people will access VET through workplaces, whether in the formal or informal economies. An important part of the accessibility challenge for VET, therefore, lies in addressing how accessibility to quality learning in work can be enhanced. There can be major benefits for employers and workers if workplaces are also sites of significant learning. However, many workplaces are not such sites and firms and even whole sectors can succeed without providing any encouragement of workers. learning. VET faces a challenge of seeking to maximise workplace learning, but this challenge also goes beyond VET to issues of sectoral and geographic organisation of work and their interrelationship with global processes of production and consumption (Felstead et al., 2011). Equally, some of the drive for improved workplace learning may come from decisions regarding the adoption of new technologies, but such decisions will also be powerfully shaped by governments' efforts to nudge producer and consumer behaviour in certain ways.

New learning technologies may offer benefits in increasing access for the previously marginalised. They can offer new ways of learning that are not only more practical in their fit with other demands on time, but are more respectful of multiple approaches to learning and varied existing funds of knowledge. Moreover, some of the new technologies also offer new possibilities for learners living with disabilities to access different forms of knowledge and skills. However, it is important to note that such technological solutions do not necessarily guarantee improved accessibility. A digital divide exists in all countries and the poorest learners are often also least able to access certain technologies. However, we need to distinguish between technologies and to be aware of the dynamics caused by their rapid evolution. For instance, there is recent evidence of the particular potential of mobile learning for reaching further into marginalised communities and groups that reflects rapid changes in what mobile communications and computing can deliver and at what cost (Kim, Miranda and Olaciregui, 2008). Nonetheless, it is important to remember that some forms of VET learning may be less conducive to purely distance learning and to recall that many learners have needs that mean they strongly benefit from face-to-face interactions with other learners and with teachers and support staff.

Tomasevski's third concern can be adapted to look at ways that VET should be increasingly accessible and of increasing quality. It may be that expanding formal VET systems may require tighter control of unit costs but widening provision cannot be done by reducing investment per learner in ways that jeopardise quality. Of course, there may be economies that come with larger scale, particularly in national public VET systems that have tiny participation. For instance, amongst the 14 countries of Southern Africa, five have fewer than 5000 learners in public VET, and most SADC member states have fewer learners nationally than a single typical provider in countries such as England or Australia. The use of e-and m-learning may also offer prospective cost savings, although the very significant start-up costs should not be forgotten. However, here too it is important to look beyond formal provision to consider how both quality and accessibility of other forms of VET can be enhanced.

Regarding Tomasevski's fourth concern, we know that formal education can be deeply exclusionary, even to many of those present. This happens through the overt and covert messages of who is welcome in the institution and which knowledges matter. Gender, race, class, ethnicity, religion, disability, HIV-status, and many more characteristics are used on a daily basis to discriminate against some learners in VET institutions worldwide. Such discrimination may be by individuals through words and actions but can be deeply institutionalised in the curriculum, timetable or facilities provided. We know too that workplaces can also manifest similar problems and that access to traditional apprenticeship, for instance, is hugely shaped by characteristics of ethnicity, gender and 
caste. There is a major challenge, therefore, in addressing the key factors that exclude people from decent learning for decent work.

Thus, a rights perspective can add to the orthodox concerns about VET. Indeed, the toolkit is increasingly being developed to address both efficiency and equity concerns. However, it is not entirely clear whether the human rights perspective, in itself, does much to disrupt the orthodoxy. Nonetheless, within a more radical view of the nature of vocational learning, it is possible to use a human rights perspective to argue for a greatly expanded set of VET policy options, as is done in the two UNESCO reports of 2012.

\section{Human Development and Capabilities}

A more transformative set of possibilities for reimagining VET may lie in a consideration of the human development and capabilities approach. In the more than 20 years of the Human Development Reports, the theory of human development has both matured and become hugely influential (UNDP, 2010). It draws clearly on many of the key insights of human rights thinking, even though its leading proponent, Sen, is suspicious of some of the tendency of the rights approach towards universalism and utopianism, as illustrated by his critique of Rawls's idea of justice (Sen, 2009). The 20th anniversary HDR provides a clear definition of the approach:

Human development is the expansion of people's freedoms to live long, healthy and creative lives; to advance other goals they have reason to value; and to engage actively in shaping development equitably and sustainably on a shared planet. People are both the beneficiaries and drivers of human development, as individuals and in groups.

Thus stated, human development has three components:

- Well-being: expanding people's real freedoms -so that people can flourish.

- Empowerment and agency: enabling people and groups to act -to drive valuable outcomes.

- Justice: expanding equity, sustaining outcomes over time and respecting human rights and other goals of society. (UNDP, 2010: 23)

Through these three components, human development thinking has broadened the range of objectives that are routinely considered in development policy discussions and downplays the centrality of economic growth, which is only one element of the Human Development Index (HDI). It is clear also that the HDI is not intended to provide universal policy answers but to serve as a contribution to reasoned and public reflection on what specific development goals should be in particular contexts (UNDP, 2010).

If the HDI has been the key tool that the human development movement has popularised, it has also been responsible for two major conceptual contributions to the theory of development. First, Sen (1999) has stressed the centrality of freedom to develop, as in the quotation above (echoing the "four freedoms" at the heart of the UN Charter [Roosevelt, 1941]). Second, he and others, most notably Nussbaum (2000 and 2003), have developed the notion of capabilities.

As Walker defines it,

A capability is a potential functioning; the list of functionings is endless. It might include doings and beings such as being well nourished, having shelter and access to clean water, being mobile, being well-educated, having paid 
work, being safe, being respected, taking part in discussions with your peers, and so on. The difference between a capability and functioning is like one between an opportunity to achieve and the actual achievement, between potential and outcome (Walker, 2006: 165).

These notions of capability and freedom are closely interrelated. Sen's approach is primarily about developing individuals' "agency freedom" to be able to act to bring about the changes that they value.

It is apparent that Sen and Nussbaum largely accept a rights-based view of education and the fundamental need for prioritisation of basic education. Sen sees education also as having an instrumental purpose in supporting other capabilities and functionings and as supportive of agency freedom more broadly. However, education has not been a major focus of his work. Although Nussbaum has come to the defence of liberal education and the humanities in some of her major works (1997 and 2010), these have not been particularly closely linked to her work on capabilities and development.

Nonetheless, there has been a growth in work in international education and development using a capabilities perspective since 2005 (e.g., Unterhalter, 2005; Walker, 2006; Walker and Unterhalter, 2007; Tikly and Barrett, 2011; Walker, 2012), most of which has also focused primarily on schooling. However, Walker et al. (2009) and Walker and McLean (2010) show how the approach can be applied to higher education, specifically to the education of professionals.

There is yet to be significant work on VET and capabilities. ${ }^{4}$ Indeed, it is instructive that the 2010 HDR, which reviews 20 years of theoretical and methodological progress in the human development approach, makes almost no mention of skills as a component of human development (there are five very brief references in 238 pages). Whilst one of these references is to a lack of skills being part of a multi-dimensional view of poverty, this is not reflected in the Multidimensional Poverty Index itself. Indeed, the closest that vocational learning comes to the three core indexes is through the inclusion of female labour force participation within the Gender Equality Index.

However, Walker et al.'s work on professional capabilities may be a useful illustrative starting point in applying capability theory to VET. Their focus is specifically on professionals working in a pro-poor way and they posit the following core capabilities for such professionals:

\section{Figure 1: Professional Capabilities}

1. Informed Vision, for example: Understanding how the profession is shaped by historical and current socio-economic-political context national and globally; understanding how structures shape individual lives; being able to imagine alternative futures and improved social arrangements.

2. Affiliation (solidarity). For example: Accepting obligations to others; care and respect for diverse people; understanding lives of poor and vulnerable; developing relationships and rapport across social groups and status hierarchies; communicating professional knowledge in an accessible way/courtesy and patience.

3. Resilience, for example: Perseverance in difficult circumstances; recognising the need for professional boundaries); fostering hope; having a sense of career security. 4. Social and collective struggle, for example: Community empowerment approach/ promoting human rights; contributing to policy formulation and implementation; identifying spaces for change/Leading and managing social change to reduce injustice;

\footnotetext{
${ }^{4}$ At least in Britain, VET and capabilities has another resonance, relating to influential work done by the Royal Society for the Encouragement of Arts, Manufactures and Commerce in which they used capabilities in an attempt to break away from divisions of practice and theory (RSA, 1979).
} 
working in professional and inter-professional teams; participating in public reasoning/ listening to all voices in the "conversation"; building and sustaining strategic relationships and networks with organisations and government.

5. Emotions, for example: Empathy/narrative imagination; compassion; personal growth; self care; integrating rationality and emotions; being emotionally reflexive. 6. Integrity, for example: Acting ethically; being responsible and accountable to communities and colleagues; being honest; striving to provide high-quality service. 7. Assurance and confidence, for example: Expressing and asserting own professional priorities; contributing to policy; having confidence in the worthwhileness of one's professional work; having confidence to act for change.

8. Knowledge, imagination, practical skills, for example: Having a firm, critical grounding in disciplinary, academic knowledge; valuing indigenous and community knowledges; having a multidisciplinary / multi-perspectival, stance; being enquiring, critical, evaluative, imaginative, creative and flexible; integrating theory and practice; being problem-solvers; open minded.

Source: Walker and McLean, 2010: 856-7

This is explicitly not intended to be a universalised list to be borrowed in other contexts. Rather, they stress the need to develop such capability sets through a dialogue between learners, teachers, professional bodies, clients and other stakeholders. Indeed, the main importance of their argument lies in offering a way of thinking both about the importance of the capability lens and how to use it in practice. From a VET perspective, it may be that this capabilities set seems to go too far in prioritising ethical and emotional dimensions instead of practical and technical domains. Nonetheless, there may be merit in using such an approach to consider what it is that VET occupations and learners actually do value and to explore the possible tensions between different views regarding the ideal capability set.

Also of use to my argument is their additional focus on the institutions that educate such professionals (see Walker et al., 2009). Their work focuses on South Africa and the particular challenges that both "public good professions" and universities have faced in shifting to a post-Apartheid model. This has led them to develop the notion of an institutional capability of connectedness. This is somewhat analogous to the VET concept of responsiveness (also used in the South African context by McGrath, 2003). However, whilst responsiveness may be criticised for privileging only the economic dimension and the views and interests of employers, connectedness is located firmly in a a social justice frame. If the real VET challenge is to provide access to high quality vocational learning for all, then institutional transformations will inevitably be an important challenge that can be informed by Walker et al.'s insights, whilst not losing sight of VET's special relationship with the worlds-of-work.

Another South African contribution, Powell's (2012) article in this special issue, potentially marks an important step forward in theorising in this area. By focusing on learners' voices and on hearing how VET has expanded their capability to choose and to aspire, she points to the real possibilities for vocational learning to contribute to the growth of individuals and communities that goes far beyond the productivist orthodoxy.

Thus, whilst the human development and capabilities approach has not afforded much attention to VET matters, it is clear that there is potential in using a capabilities lens to think about what could be learnt in different VET settings and how. However, it is in its broader sense of human development as going far beyond the economic domain that the approach is most valuable. A wider focus on well-being and agency can help in the construction of a more radical notion of learning for life. In this, vocational learning can play a crucial role in supporting learning for multiple purposes. Such purposes may include the following:

. for cultural purposes, as in learning Chinese calligraphy; 
Pre-Press copy of paper in IJED 32/5

doi: http://dx.doi.org/10.1016/j.ijedudev.2011.12.001

. for leisure purposes, such as learning woodworking for personal fulfilment rather than trade;

. for communicative purposes, as in "third age" learning of how to use email to keep in touch with dispersed families;

. for caring purposes, such as developing skills to care for people living with AIDS, for non-commercial purposes;

. for spiritual development purposes, as in learning to improve one's ability to communicate religious ideas to one's children; and

. for community development purposes, such as building skills to facilitate community projects.

A key insight of the capabilities approach, however, is that such lists should simply be illustrative, as it is for individuals to identify the learnings-for-lives that are of value to them, as Powell's article clearly illustrates. However, such an insight also calls those who are responsible for planning, delivering or facilitating VET to consider how it requires transformation to meet the wide range of vocational learning purposes that may exist.

\section{Integrated Human Development ${ }^{5}$}

This expanded notion of vocational learning makes greater sense if placed within a notion of a broader human vocation to learn and develop. Such an understanding can be advanced by considering a third strand of human-centred development. The first two strands I have engaged with are primarily rooted in secular traditions. However, the third I wish to examine is explicitly from a religious perspective, specifically a Catholic one. Whilst there has been a growing sense of the importance of religion in development in recent years (cf. Deneulin with Bano, 2009; Marshall, 2010; Theos, 2010), there has been little engagement with the insights of approaches such as the Catholic account of integrated human development (IHD) within the academic community, in spite of the major resonances of this account with some of the strands of human-centred development (see Plant, 2009, for an exercise in bridge building from the theological side).

Whilst the previous two accounts developed from the work of the United Nations, IHD has its roots in the magisterium, or teaching office, of the Catholic Church and, specifically in papal pastoral writings, most notably in a number of encyclicals, or teaching letters. In a series of encyclicals from Rerum Novarum (Of New Things) in 1891 to Caritas in Veritate (Charity in Truth) in 2009, successive popes have developed an account of Catholic social teaching that has responded first to the nature and impacts of the Industrial Revolution in Europe; subsequently to the rise, and then fall, of Communism; and latterly to international development. At the heart of these encyclicals is a rejection of modernity's market-state dialectic and a robust critique of both communism and capitalism as models of economic and social development.

In these encyclicals, but especially in Populorum Progressio (The Development of Peoples) (1967), we can see anticipations of key elements of current human-centred development accounts, such as freedom, peace, human security, intergenerational

\footnotetext{
${ }^{5}$ The terminology around human development theory can be confusing as there are lots of terms that are used in multiple ways (see my footnote regarding capabilities). Here, I am using Integrated Human Development as it refers to a well-established approach that is part of the wider Catholic Social Teaching tradition.
} 
Pre-Press copy of paper in IJED 32/5

doi: http://dx.doi.org/10.1016/j.ijedudev.2011.12.001

responsibility and environmental stewardship. For example,

We are the heirs of earlier generations, and we reap benefits from the efforts of our contemporaries; we are under obligation to all men. Therefore we cannot disregard the welfare of those who will come after us to increase the human family. (Paul VI, 1967: 17) ${ }^{6}$

This account stresses the need to balance a rights approach with a sense of human duties: "Collaboration in the development of the whole person and of every human being is in fact a duty of all towards all." (John Paul II, 1987: 32).

This account is also aware of the dangers of uneven development, and a growing gap between rich and poor, but also very concerned with the danger of "superdevelopment": In poorer areas some groups enjoy a sort of "superdevelopment" of a wasteful and consumerist kind which forms an unacceptable contrast with the ongoing situations of dehumanising deprivation. (Benedict XVI, 2009: 23)

Against this is posited a transcendent view of integral human development in which God's relationship to humanity is at the centre. This stresses the unconditional value of the human person and a focus on all aspects of humanity. In this light, Populorum Progressio appears to anticipate Sen by more than a quarter-century when it argues:

It is not just a question of eliminating hunger and reducing poverty. It is not just a question of fighting wretched conditions, though this is an urgent and necessary task. It involves building a human community where men [sic] can live truly human lives, free from discrimination on account of race, religion or nationality, free from servitude to other men or to natural forces which they cannot yet control satisfactorily. It involves building a human community where liberty is not an idle word. (Paul VI, 1967: 47)

This leads to a stress on human dignity as core to human development (Leo XIII, 1891). This notion is built on three pillars: the common good, solidarity and subsidiarity (Pontifical Council for Justice and Peace, 2004).

The common good is seen as "the sum total of social conditions which allow people, either as groups or as individuals, to reach their fulfilment more fully and more easily" (Paul VI, 1965: 26). Thus, it goes beyond both the individual and the economic.

Solidarity is an expression of the view that individuals owe a debt to society and to others, intergenerationally. In this sense, individual freedom is meaningful only in social context (Pontifical Council for Justice and Peace, 2004).

Subsidiarity argues for a bias in favour of the autonomy of individuals and the organisations of civil society in public policy. It argues that the state should get involved only when the lower level cannot do what is necessary to ensure the common good. It stresses that individuals' and civil society organisations' "initiative, freedom and responsibility must not be supplanted" (Pontifical Council for Justice and Peace, 2004: 186).

Together, these concepts lead to a view of participation in development as a duty of all people, and an argument that person-centred development must be built on the existing capacities of people rather than being driven by development professionals. In Ellerman's terms (2005 and 2007), it must be autonomy enhancing.

\footnotetext{
${ }^{6}$ Given the unfamiliarity of this literature to IJED readers, when compared to the other two strands, I will quote at greater length in this part.
} 
Crucially for the focus of this paper on VET, Catholic social teaching has also developed an account of the dignity of labour, which has evolved from late 19th Century concerns with the threat of revolution into an account that engages explicitly with the International Labour Organisation's decent work agenda.

As Benedict XVI makes clear, work is one of the most central elements of development. Equally, the Pontifical Council for Justice and Peace (PCJP) argues that work is the "essential key" to the whole social question and is the condition not only for economic development but also for the cultural and moral development of persons, the family, society and the entire human race. (2004: 269)

In this tradition, work is part of being human and is a global public good:

Work is a good belonging to all people and must be made available to all who are capable of engaging in it. "Full employment" therefore remains a mandatory objective for every economic system oriented towards justice and the common good. (Pontifical Council for Justice and Peace, 2004: 288)

Work should never lead to alienation or to the instrumentalisation of the worker. Rather, work should always be decent:

What is meant by the word "decent" in regard to work? It means work that expresses the essential dignity of every man and woman in the context of their particular society: work that is freely chosen, effectively associating workers, both men and women, with the development of their community; work that enables the worker to be respected and free from any form of discrimination; work that makes it possible for families to meet their needs and provide schooling for their children, without the children themselves being forced into labour; work that permits the workers to organise themselves freely, and to make their voices heard; work that leaves enough room for rediscovering one's roots at a personal, familial and spiritual level; work that guarantees those who have retired a decent standard of living. (Benedict XVI, 2009: 63)

The PCJP also argues that VET systems should take a lifelong perspective to skills development needs. This should include development of young people's capacities to take the initiative in seeking employment opportunities and to be able to respond to dynamic labour markets. It also should include retraining for those adults in and out of employment, as necessary (Pontifical Council for Justice and Peace, 2004).

The integral human development approach usefully takes our thinking to an even broader level but also brings it back closer to the worlds-of-work and the conventional concerns of VET. In its emphasis on transcendence it allows us to think of vocational learning as being linked to the vocation of becoming fully human, whether we see this in theological terms or not. Thus, it potentially broadens the already expanded notion of development present in the human development account and reinforces the argument that vocational learnings will be multi-dimensional. Through subsidiarity, it reinforces Sen's concept of agency freedom to make it clear that what counts as valuable learning is for individuals and communities to decide.

Yet, it also usefully regrounds our thinking about vocational learning through its insistence on the centrality of work to development. This allows for a link to be made to the various secular philosophical strands that have stressed the importance of vocational learning as the construction of character and values. 
Winch's work is most useful in helping explore this secular tradition further. One strand of his work (e.g., Winch 1998 and 2006) has sought to show how German theorists of vocational learning, such as List (in the 19th century) and Kerschensteiner (in the 20th), stressed not just the technical dimension but also the moral and social aspects of vocational learning that made it both civic and liberal. For Winch, this German tradition stresses the creation of not just skills, but the virtues of diligence, patience, self-mastery and perseverance. These are learnt not so much in theoretical study but through engagement in practical problem solving and through interaction in the workplace where character formation arises out of an encounter with the traditions and standards of the occupation.

Winch also echoes significant themes of the IHD approach in making an explicit liberal case for vocational education in which he stresses the ability to earn a living through meaningful work as an important part of the function of liberal education (Winch 2000). He argues that moral education must include being able to choose a worthwhile mode of life and acceptable ways of achieving it. This leads him to suggest that "A concern with the aims of and constraints on one's chosen occupation is, arguably, an important matter in the moral formation of a future worker" (Winch 2000: 71), an argument reminiscent of both Sen and Benedict XVI.

Through its focus on the dignity of work as paramount to human development, the Catholic tradition makes it clear that progressive VET and decent work require a radical reordering of the way that capitalism operates. This provides a bridge to the concerns of the political economy of skills tradition that sees VET as being shaped by historical, cultural and political factors (e.g., Ashton and Green, 1996; Crouch, Finegold and Sako, 1999; Brown, Green and Lauder, 2001; McGrath et al., 2004).

\section{Conclusion: The Imperative to Build a Human-Centred Development Account of VET}

I have argued in this article that we have a real opportunity at this moment to consider what the purpose of vocational education and training is and how this is understood in the context of development theory. This provides a complementary account to those, such as Winch, who have addressed this through other traditions. Importantly, the development lens can help to broaden the debate from its core concern with OECD, and particularly Anglophone developed country, contexts. However, I do not wish to posit a Southern-oriented account alongside the Northern one, but to suggest that the theoretical lenses used here offer the possibility of thinking globally, whilst still (particularly in the capabilities tradition) remaining mindful of context.

This article is explicitly set outside the current orthodoxy and this brings with it the risk of being too polemical. I am not denying that the current VET toolkit does have its merits. Its attention to the failings of conventional public VET, such as low pass rates; poor labour market insertion; poorly qualified teachers; inadequate resources; low curricular relevance; dead-end qualifications; and high inefficiency, is worthy of respect. Equally, it has shown itself to be increasingly able to address, at least partially, issues of equity, lifelong learning and sustainability, and to better encompass diverse sites of vocational learning.

Furthermore, more practical advocates of maintaining the VET orthodoxy will argue that the potential for further improvement in the above areas is such that this is where attention should be directed. They will suggest that, to succeed, VET must remain narrowly focused on employability, productivity and economic development. However, I have suggested that the current dominant approach to VET internationally is located firmly within an economic view of development, what Giddens has called "productivism", 
which is inadequate for dealing with core VET challenges, largely because of its impoverished notion of development, work and humanity. Instead, my core message is that it is necessary to look beyond the paradigm to imagine a new future for vocational learning that reflects the rise of alternative development theories.

The human rights perspective has played a valuable role in stressing the importance of educational access. Although EFA will not meet its goals by 2015 , its achievements are very real. However, the partial success and partial failure of EFA points to the need to address education more broadly (King, McGrath and Rose, 2007). I have argued that Tomasevski's seminal work on a rights-based theory of educational access can be expanded to include multiple forms and sites of vocational learning to posit a new right to vocational learning for all. However, to realise this there will be a serious challenge in ensuring high quality across disparate sites and modes. Moreover, it will be necessary to go beyond the human rights approach to incorporate conceptions of human development and decent work, as are offered by the other human-centred development approaches I have addressed.

The human development and capabilities approach asks far broader questions about the nature of development than the human rights account. Through linking justice, agency and well-being, it allows for a wider and more person-centred theory and practice of learnings-for-lives. A capability-enhancing perspective also stresses the empowering nature of VET alongside the technical aspect, with significant curricular and pedagogic implications. Moreover, the application of capabilities thinking to professional and vocational learning in South Africa by Walker et al. and Powell opens up the possibility for a new approach to thinking and doing vocational education that looks at the capabilities to be developed both by learners and institutions and which affirms their agency in this process.

As noted above, the insights of Catholic social teaching both allow us to think of VET as being linked to the vocation of becoming fully human and regrounds our thinking about vocational learning through its insistence on the centrality of work to development. It complements the moral philosophical approach that Winch has brought to thinking about vocational education but also relates the possibility for progressive VET and decent work to the way that capitalism operates, thus providing a bridge to the concerns of the political economy of skills tradition.

Taken together, these three elements of the broader human-centred development tradition do not provide a new theory of vocational learning for development. Rather, their value is three-fold. First, they show why we need to get beyond current narrow conceptions of VET. Second, they offer some fruitful directions for wider debate regarding the purposes, natures and possibilities of VET. Third, they encourage a shifting of the focus of VET research away from the domination of a technicist view that privileges a focus on systems and institutions, and their efficiency, towards more humanistic approaches that place individuals at the heart of research, as subjects as well as objects.

\section{References}

Allais, S. this issue

Alston, P., Robinson, M., (Eds.), 2005. Human Rights and Development. Oxford University Press, New York.

Anderson, D., 2009. Productivism and ecologism: changing dis/courses in TVET. In Fien, J., Maclean, R. and Park, M.-G., (Eds.). Work, Learning and Sustainable Development. Springer, Dordrecht. 
Pre-Press copy of paper in IJED 32/5

doi: http://dx.doi.org/10.1016/j.ijedudev.2011.12.001

Ashton, D., Green, F., 1996. Education, Training and the Global Economy. Edward Elgar, Cheltenham.

Benedict XVI, 2009. Caritas in Veritate. Available at http://www.vatican.va/holy_father/benedict_xvi/encyclicals/documents/hf_benxvi_ enc_20090629_caritas-in-veritate_en.html, last accessed on 16/06/11.

Bennell, P., 1996. Using and abusing rates of return: a critique of the World Bank's 1995 Education Sector Paper. International Journal of Educational Development 16, 3, 235-248.

Bennell, P., Segerstrom, J., 1998. Vocational education and training in developing countries: has the World Bank got it right? International Journal of Educational Development 18, 4, 271-287.

Brockmann, M., Clarke, L. and Winch, C., (Eds.) 2011. Knowledge, Skills and Competence in the European Labour Market. Routledge, Abingdon.

Brown, P., Green, A., Lauder, H., 2001. High Skills. Oxford University Press, Oxford.

Cedefop, 2011. Despite its many benefits, vocational education and training lacks esteem. Cedefop, Thessaloniki.

Colley, H., James, D., Diment; K. and Tedder, M., 2003. Learning as becoming in vocational education and training: class, gender and the role of vocational habitus. Journal of Vocational Education and Training 55, 4, 471-498.

Crouch, C., Finegold, D., Sako, M., 1999. Are Skills the Answer? The Political Economy of Skill Creation in Advanced Industrial Societies. Oxford University Press, Oxford.

Deneulin, S., Bano, M., 2009. Religion in Development: Rewriting the Secular Script. Zed, London.

Edigheji, O., (Ed.), 2010. Constructing a democratic developmental state in South Africa: potentials and challenges. HSRC Press, Cape Town.

Ellerman, D., 2005. Helping People Help Themselves: From the World Bank to an Alternative Philosophy of Development Assistance. University of Michigan Press, Ann Arbor.

Ellerman, D., 2007. Helping self-help: The fundamental conundrum of development assistance. The Journal of Socio-Economics 36, 561-577.

Felstead, A., Fuller, A., Jewson, N., Unwin, L., 2011. Working to learn, learning to work. Praxis Working Paper 7, UK Commission for Employment and Skills, Wath-Upon-Dearne.

Fischer, A., 2009. Putting aid in its place: Insights from early structuralists on aid and balance of payments and lessons for contemporary aid debates. Journal of International Development 21, 6, 21, 856-67.

Foster, P., 1965. The vocational school fallacy in development planning. In Anderson, C. and Bowman, M. (Eds.). Education and economic development. Aldine, Chicago

Gasper, D., 2007. Human rights, human needs, human development, human security: Relationships between four international "human"

discourses. Institute of Social Studies,

The Hague. 
Pre-Press copy of paper in IJED 32/5

doi: http://dx.doi.org/10.1016/j.ijedudev.2011.12.001

Giddens, A., 1994. Beyond Left and Right. Polity, Cambridge.

Heyneman, S., 1985. Diversifying secondary school curricula in developing countries: an implementation history and some policy options. International Journal of Educational Development 5, 4, 283-288.

John Paul II, 1987. Sollicitudo Rei Socialis. Available at http://www.vatican.va/edocs/ENG0223/_INDEX.HTM, last accessed on 16/06/11.

Karmel, T., 2011. As clear as mud: Defining vocational education and training. National Centre for Vocational Education Research, Adelaide.

Kim, P., Miranda, T., Olaciregui, C., 2008. Pocket school: Exploring mobile technology as a sustainable literacy education option for underserved indigenous children in Latin America. International Journal of Educational Development 28, 4, 435-445.

King, K., 2009. Education, skills, sustainability and growth: Complex relations. International Journal of Educational Development 29, 2, 175-181.

King, K., this issue

King, K., Martin, C., 2002. The vocational school fallacy revisited: education, aspiration and work in Ghana 1959-2000. International Journal of Educational Development 22, 1, 5-26.

King, K., McGrath, S., Rose, P., 2007. Beyond the basics: educating and training out of poverty. International Journal of Educational Development 27, 4, 349-357.

King, K., Palmer, R. 2011. New trends in international cooperation. Background paper for the World Report on Technical and Vocational Education Training.

Lauglo, J., Lillis, K. (Eds.), 1988. Vocationalising education. Pergamon, Oxford.

Leo XIII, 1891. Rerum Novarum. Available at

http://www.vatican.va/holy_father/leo_xiii/encyclicals/documents/hf_Ixiii_ enc_15051891_rerum-novarum_en.html, last accessed on 16/06/11.

Lewis, T., 2009. Towards reclaiming the high ground in the discourse on vocationalism in developing countries. International Journal of Educational Development 29, 6, 558-64.

Marshall, K., 2010. Education for All: Where does religion come in? Comparative Education 46, 3, 273-287.

McGrath, S., 2003. Researching responsiveness. In Cosser, M., McGrath, S., Badroodien, A. and Maja, B., (Eds.). Technical College Responsiveness. HSRC Publishers, Cape Town

McGrath, S., 2010. Beyond aid effectiveness: The development of the South African further education and training college sector, 1994-2009. International Journal of Educational Development 30, 5, 525-534.

McGrath, S., 2011. Where to now for vocational education and training in Africa? International Journal of Training Research 9, 1\&2, 35-48.

McGrath, S., Akoojee, S., 2007. Education and skills for development in South Africa:

Reflections on the accelerated and shared growth initiative for South Africa. International Journal of Educational Development 27, 4, 421-434. 
Pre-Press copy of paper in IJED 32/5

doi: http://dx.doi.org/10.1016/j.ijedudev.2011.12.001

McGrath, S., Akoojee, S., 2009. Vocational education and training for sustainability in South Africa: The role of public and private provision. International Journal of Educational Development 29, 2, 149-156.

McGrath, S., Badroodien, A., Kraak, A., Unwin, L., (Eds.), 2004. Shifting Understandings of Skill. HSRC Press, Cape Town.

Muller, T., 2011. Introduction to human resources development versus the right to education: Reflections on education policy making. Journal of International Development $23,2,253-61$.

Nussbaum, M., 1997. Cultivating Humanity. Harvard University Press, Cambridge MA.

Nussbaum, M., 2000. Women and Human Development: The Capabilities Approach. Cambridge University Press, Cambridge.

Nussbaum, M., 2003. Capabilities as fundamental entitlements: Sen and social justice. Feminist Economics 9, 2, 33-59.

Nussbaum, M., 2010. Not for Profit. Princeton University Press, Princeton.

Palmer, R., 2007. Skills for work?: From skills development to decent livelihoods in Ghana's rural informal economy. International Journal of Educational Development 27, 4, 397-420.

Palmer, R., 2009. Skills development, employment and sustained growth in Ghana: Sustainability challenges. International Journal of Educational Development 29, 2, 133 139.

Paul VI, 1967. Populorum Progressio. Catholic Institute for International Relations, London.

Plant, S., 2009. International development and belief in progress. Journal of International Development 21, 6, 844-55.

Pontifical Council for Justice and Peace, 2004. Compendium of the Social Doctrine of the Church. Libreria Editrice Vaticana, Vatican City.

Powell, L., this issue.

Psacharopoulos, G., 1981. Returns to education: an updated international comparison. Comparative Education 17, 3, 321-341.

Psacharopoulos, G., 1985. Returns to education: a further international update and implications. Journal of Human Resources 20, 4, 583-604.

Psacharopoulos, G., Loxley, W., 1985. Diversified secondary education and development. Johns Hopkins University Press, Baltimore.

Rawls, J., 1971. A Theory of Justice. Belknap, Cambridge MA.

Roosevelt, F., 1941. Annual message to Congress on the state of the Union, 1941. Available at http://www.fdrlibrary.marist.edu/pdfs/fftext.pdf, accessed on 16/06/11.

RSA, 1979. Education for capability manifesto. Royal Society for the Encouragement of Arts, Manufactures and Commerce, London. 
Pre-Press copy of paper in IJED 32/5

doi: http://dx.doi.org/10.1016/j.ijedudev.2011.12.001

Sen, A., 1999. Development as Freedom. Oxford University Press, Oxford.

Sen, A., 2009. The Idea of Justice. Allen Lane, London.

Strathdee, R., 2011. The implementation, evolution and impact of New Zealand.s national qualifications framework. Journal of Education and Work 24, 3\&4, 303-321.

Theos, 2010. Human Flourishing. Theos, London.

Tikly, L., Barrett, A., 2011. Social justice, capabilities and the quality of education in low income countries. International Journal of Educational Development 31, 1, 3-14.

Tomasevski, K., 2001. Human rights obligations. Available at http://www.righttoeducation.org/content/primers/rte_03.pdf, last accessed on 15/01/08.

UN, 1948. Universal Declaration on Human Rights. United Nations, New York.

UNDP, 1990. Human Development Report, 1990. Oxford University Press, Oxford.

UNDP, 2010. Human Development Report, 2010. Oxford University Press, Oxford.

Unterhalter, E., 2005. Global inequality, capabilities, social justice: The millennium development goal for gender equality in education. International Journal of Educational Development 25, 2, 111-22.

Unwin, L., 2004. Growing beans with Thoreau: Rescuing skills and vocational education from the UK's deficit approach. Oxford Review of Education 30, 1, 147-60.

Walker, M., 2006. Towards a capability-based theory of social justice for education policymaking. Journal of Education Policy 21, 2, 163-185.

Walker, M., 2012. A capital or capabilities education narrative in a world of staggering inequalities. International Journal of Educational Development, in press.

Walker, M., McLean, M., 2010. Making lives go better: University education and "professional capabilities". South African Journal of Higher Education 24, 5, 847-69.

Walker, M., McLean, M., Dison, A., Peppin-Vaughan, R., 2009. South African universities and human development: Towards a theorisation and operationalisation of professional capabilities for poverty reduction. International Journal of Educational Development, 29, 6, 565-572.

Walker, M., Unterhalter, E., (Eds.), 2007. Amartya Sen's Capability Approach and Social Justice in Education. Palgrave Macmillan, New York.

Watson, K., 1994. Technical and vocational education in developing countries: Western paradigms and comparative methodology. Comparative Education 30, 2, 85-97.

Winch, C., 1998. Two rival conceptions of vocational education: Adam Smith and Friedrich List. Oxford Review of Education 24, 3, 365-78.

Winch, C., 2000. Education, Work and Social Capital. Routledge, London.

Winch, C., 2002. Work, well-being and vocational education: The ethical significance of work and the preparation for work. Journal of Applied Philosophy 19, 3, 261-71. 
Pre-Press copy of paper in IJED 32/5

doi: http://dx.doi.org/10.1016/j.ijedudev.2011.12.001

Winch, C., 2006. Georg Kerschensteiner: founding the dual system in Germany. Oxford Review of Education 32, 3, 381-96.

World Bank, 1991. Vocational and Technical Education and Training. World Bank, Washington. 
Pre-Press copy of paper in IJED 32/5

doi: http://dx.doi.org/10.1016/j.ijedudev.2011.12.001 